УДК 821.161.2.

О. Б. Каневська, С. В. Щербак

\title{
РОЗГАЛУЖЕНІСТЬ, СКЛАДНІСТЬ І ВЗАЕМОДІЯ ОБРАЗІВ РОМАНУ «АПОСТОЛ ЧЕРНІ» ОЛЬГИ КОБИЛЯНСЬКОЇ
}

Каневська О. Б., Щербак С. В. Розгалуженість, складність і взаємодія образів роману «Апостол Черні» Ольги Кобилянської.

У статті на основі аналізу роману О. Кобилянської «Апостол Черні» прослідковано розгалуженість, складність і взаємодія системи образів твору, що дає можливість виявити авторські особливості підходу до створення художніх образів.

Ключові слова: роман, письменниця, система образів, авторській підхід, розгалуженість.

Каневская О. Б., Щербак С. В. Разветвленность, сложность и взаимодействие образов романа «Апостол Черни» Ольги Кобылянской.

В статье на основе анализа романа О. Кобылянской «Апостол Черни» охарактеризованы разветвленность, сложность и взаимодействие системы образов произведения, что дает возможность выявить авторские особенности подхода к созданию художественных образов.

Ключевые слова: роман, писательница, система образов, авторский подход, разветвленность.

Kanevskaya O. B., Shcherbak S. V. The branching structure, the complexity and interaction of the images of the novel «The Apostle mobile» Olga Kobylyanska.

In article on the basis of the analysis of the novel O. Kobylyanska «The Apostle mobile» Procman branching, the complexity and interaction of the system of images of works, which makes it possible to identify the author's particular approach to the creation of artistic images.

Key words: novel, writer, system images, the author's approach, the branching structure.

Творчість Ольги Кобилянської припадає на період зламу XIX i XX століть, у той час, коли в літературі відбувалися творчі шукання, які отримали назву модернізм. Письменниця не залишалася осторонь від літературного життя своєї доби, вона активно творила переважно в руслі неоромантичних традицій.

Ольга Кобилянська працювала в різноманітних жанрах великої й малої прози, у її творах розкривалися події Першої світової війни та довоєнне життя, героями були представники селянства, інтелігенції, міщанства. Письменниця чи не вперше в українській літературі підняла тему емансипації жінки, зображуючи сильну й незалежну особистість, що обстоює права жінки. Проблеми, порушувані авторкою у творах, є важливими й актуальними і для сьогоднішньої

- 189 - ๑ О. Б. Каневська, С. В. Щербак, 2014. 
доби, для теперішнього читача, оскільки зображуване у творчості Ольги Кобилянської хвилює і наших сучасників.

Творчий шлях видатної письменниці, поетика іiі творів стали предметом дослідження багатьох літературознавців (В. Агєєва, Л. Білецький, . Гузар, Т. Гундорова, М. Свшан, М. Лещенко, С. Павличко, В. Саєнко та інші). Але не всі питання,що стосуються аналізу іiі творів, індивідуально-авторського стилю, $є$ розв'язаними. Тому, ураховуючи сучасні підходи до осмислення творчості письменниківмодерністів, доцільним видається поглиблення аналітичної роботи 3 твором Ольги Кобилянської «Апостол черні».

Мета статті - 3'ясувати специфіку втілення характерів персонажів у творі О. Кобилянської «Апостол черні».

У 1922 році О. Кобилянська завершує дві книги великого твору «Апостол черні» (надрукований у 1926 році), присвяченого висвітленню проблем соціально-громадського життя тогочасної Буковини, іiі різних верств населення. Проте основну увагу письменниця зосередила на питанні значення інтелігенції в суспільному житті [1, с. 64]. I. Демченко підкреслює: «Як і в багатьох своїх творах, Кобилянська в «Апостолі черні» використовує матеріали 3 життя родини Кобилянських, особливо 3 життя попередніх іiі поколінь. У цій частині чимало цікавих картин із життя галицьких і буковинських поміщиків, а також малозаможних шляхтичів, змушених служити управителями у графів» [2, с. 17].

Роман «Апостол черні», який спочатку мав називатися «Юліан Цезаревич», писався досить довго: письменниця розпочала його ще напередодні імперіалістичної війни. Твір друкувався протягом кількох років із перервами у празькому журналі «Нова Україна», а потім повністю вийшов у двох книжках у Львові, відредагований і дещо скорочений В. Сімовичем.

Роман О. Кобилянської, густо населений i поліфонічний, присвячений розв'язанню багатьох актуальних для того часу проблем (наприклад, батьків і дітей: батько і син, батько і його три доньки, бабуня і зв'язок поколінь тощо), висвітлює передусім головну проблему національної інтелігенції, на плечі якої письменниця поклала обов'язок шукати шляхів боротьби за власну державу.

Проблема становлення української інтелігенції розв'язується письменницею через зображення складних стосунків між родинами та між поколіннями, їх узаємовпливами. Наприклад, родина Еви впливає на родину Цезаревичів, особливо на Юліана Цезаревича, саме через це ๑ О. Б. Каневська, С. В. Щербак, 2014. 
він спочатку приймає богослов'я, а пізніше йде до війська; ворожнеча між родинами Альбінських та Цезаревичів припиняється завдяки Дорі, яка покохала Юліана тощо.

Отже, художній хроном роману охоплює долі людей трьох поколінь і трьох родин - Цезаревичів, Захаріїв та Альбінських. Не нові у звичному розумінні проблеми (батьків і дітей, обов'язку і владних амбіцій, кохання молодих, що репрезентують ворогуючі ряди), завдяки основному стрижневі - міцному сплавові моральноетичного та національно-патріотичного аспектів, - підпорядкована проблемі виховання українців-державників.

Головний герой роману - Юліан Цезаревич - намагається стати «ідеальним християнином», «апостолом Черні», що сіяв Христову науку, студіює теологію, але, молодий і сильний, стає офіцером «апостолом меча» (дуже ненав'язливо письменниця утверджує ідею української військової могутності). У цьому персонажі поєднуються такі важливі, на думку Ольги Кобилянської, риси особистості, як: національна свідомість аж до мислення державницькими категоріями, твердість характеру, освіченість, джентльменство, «любов до своєї мови і нації». Виховною перспективою, накресленою в романі «Апостол черні», стає необхідність розвитку духовності, яка грунтується на національно-історичному почутті та християнських заповідях.

Виразником національних i християнських ідей у романі стає о. Захарій. Саме він $є$ цей «апостолом черні», «ідеальним душ пастирем», його характеристика від автора пряма і виразна: Був без лакомства на матеріальні здобутки, викладав дітям під голим небом Христову науку, вчив їх любити і шанувати один одного, тримаючись з собою, любити землю і поборювати брехню, хоч би яку дрібненьку [3, с.79]. Він розуміє, якою страшною $\epsilon$ «сірість» для людини. Життя священика має бути «апостольським». В уста о. Захарія письменниця вкладає слова 3 наріжним значенням: Наш нарід $е$ тою клавіатурою, з якою можна $i$ мусимо добути звуки, щзо стали б з часом викінченим мистецьким твором. Апостол черні мусить бути і творчим духом моралі, серия та ума. Мусить ним справді наскрізь бути - не фарисойствувати в користь особистих, егоїстичних иілей, нижчих від то «черні», між якою живе $i$ годується [3, с.79]. О. Захарій не підтримує тих українців, які емігрують за море, «де машини і гроші світ обертають», він говорить, що у цьому світі наша людина «почувається, мов справжня тварина», стає «хитрішою», але не розумнішою. Етична програма о. Захарія не тільки 
охоплює християнські заповіді, але й просякнута любов'ю до рідної землі, до України.

Зображені в романі персонажі складають певну систему, що презентує риси українського національного характеру, 3-поміж яких важливими $\epsilon$ сентиментальність, гнучкість, довготерпіння, флегматичність. Окрім вихідців з родини Цезаревичів, майже всі інші персонажі уособлюють саме такі риси. I священик Захарій, і його паніматка, і вчитель Рибка, і чоловіки Юліанових сестер - це типові фігури українців, що вибудовують державність подумки (мріють), але не вдаються до радикальних дій. Навчання дітей рідної мови чи наспівування українських пісень не просунуть українців до державності. О. Кобилянська змогла об'єктивно поцінувати українців як націю і художньо відтворити деякі складові менталітету.

Підкреслимо, що розкриттю характерів героїв сприяє вміле використання письменницею різноманітних художніх засобів i прийомів. Важливу роль у створенні образів персонажів також відіграють їх портретні характеристики (Юліан і Максим Цезаревичі, Дора, Ева): Юлін гарний, темноволосий, з ясними очима, струнким ростом батька та ледве замітною мімікою брів, щуо надавало йому молодому обличчю вираз задумливості, у школі мав симпатію у свойх товарищів і вчителів. Був дуже щиирий і сміливий [3, с. 12]; Оксана мала темне волосся, з класичним профілем, блідавої цери $і$ сталевої барви очима та чудно привабливим усміхом [3, с. 11], інохарактеристики, насамперед зображення персонажів через розповіді про них інших героїв (наприклад, образ Едварда подається через розповідь Максима Цезаревича, ставлення Дори до тьоті Ціллі, досить багато говорить Юліан Цезаревич про свого батька тощо).

Крім безперечних здобутків, у доробку О. Кобилянської 3'являються і деякі такі речі, що свідчать про певний спад у творчості.

Зазначимо, що роман «Апостол черні», який $\epsilon$ безперечним здобутком у творчому доробку Ольги Кобилянської, свідчить також про посилення суперечностей у іiі світогляді, надлишковою ідеалізацією представників духовного сану. Проте в цьому великому полотні $\epsilon$ чимало проникливо змальованих картин української дійсності кінця XIX - на початку XX ст., талановито виписаних образів. Письменниці вдалося колоритно й правдиво змалювати окремі картини життя й побуту різних верств населення Буковини, показати народження в цьому краї української інтелігенції.

(ㅇ О. Б. Каневська, С. В. Щербак, 2014. 
Загалом аналіз твору Ольги Кобилянської «Апостол черні» засвідчив, що письменниця зазнала творчої еволюції, передусім на жанрово-тематичному рівні, подавши текст, у якому сплелися риси роману ідей, роману виховання, сімейного та інтелектуального роману.

\section{Література}

1. Бортиняк М. Гірська орлиця / М. Бортиняк // Дивослово. - 2003. - № 3. C. 64-65.

2. Демченко I. Національно-історичне почуття як вияв духовності (Апостол Черні О. Кобилянської) / І. Демченко // Література. Фольклор. Проблеми поетики : зб. наук. праць. - К., 2001. - Вип. 9. - С. 74-81.

3. Кобилянська О. Апостол черні / О. Кобилянська - Л. : Каменяр, 1994. - 247 с.

Стаття надійшла до редакиії 30.10.2014 p. 